\title{
GMR
}

\section{Cytogenetic analysis of Triatoma pseudomaculata Corrêa and Espínola, 1964 (Hemiptera, Triatominae) from different Brazilian states}

\author{
C.H.L. Imperador ${ }^{1}$, K.C.C. Alevi ${ }^{1}$, J. Oliveira ${ }^{2}$, J.A. Rosa ${ }^{2}$ and \\ M.T.V. Azeredo-Oliveira ${ }^{1}$ \\ ${ }^{1}$ Laboratório de Biologia Celular, Departamento de Biologia, \\ Instituto de Biociências, Letras e Ciências Exatas, \\ Universidade Estadual Paulista "Júlio de Mesquita Filho", \\ São José do Rio Preto, SP, Brasil \\ ${ }^{2}$ Laboratório de Parasitologia, Departamento de Ciências Biológicas, \\ Faculdade de Ciências Farmacêuticas, \\ Universidade Estadual Paulista "Júlio de Mesquita Filho", Araraquara, SP, Brasil \\ Corresponding author: K.C.C. Alevi \\ E-mail: kaiochaboli@hotmail.com \\ Genet. Mol. Res. 15 (1): gmr.15016937 \\ Received June 3, 2015 \\ Accepted November 13, 2015 \\ Published March 31, 2016 \\ DOI http://dx.doi.org/10.4238/gmr.15016937
}

ABSTRACT. Triatoma maculata and T. pseudomaculata are allopatric; however, it is believed that $T$. maculata was introduced into the Brazilian northeast by passive transportation of the nymphs between the feathers of migratory birds, followed by the speciation of T. pseudomaculata. T. pseudomaculata is the second most epidemiologically important species in the northeast of Brazil after $T$. brasiliensis. Therefore, given the broad range of $T$. pseudomaculata, the objective of the present study was to cytogenetically analyze different populations of $T$. pseudomaculata from different Brazilian states in order to investigate possible intraspecific chromosomal variation between them. Three adult T. pseudomaculata males from each population (Pernambuco, Ceará, Paraíba, Bahia, Rio Grande do Norte, and Piauí) were analyzed by lacto-acetic orcein and C-banding. All of 
the specimens analyzed exhibited the same cytogenetic characteristics, i.e., 22 chromosomes (20 autosomes and $X Y$ ), a chromocenter formed by the $X$ and $Y$ sex chromosomes and one pair of autosomes, and heterochromatin blocks in three or four pairs of autosomes. These data confirm that all of the populations analyzed were T. pseudomaculata, and although they may be subject to different selection pressures they have maintained the genetic integrity that characterizes the species.

Key words: Cytogenetics; Chromosomal homogeneity; Triatominae subfamily

\section{INTRODUCTION}

The triatomines are insects that belong to the Hemiptera order, Heteroptera suborder, Reduviidae family, and Triatominae subfamily (Lent and Wygodzinsky, 1979). These organisms are characterized by one pair of hemelytra wings, one pair of membranous hind wings, and a buccal sucking apparatus (Schofield, 1994). The Triatominae is composed of 150 species, grouped in 18 genera and six tribes (Alevi et al., 2015a). All of the species of the subfamily are bloodsucking and potential vectors of the Trypanosoma cruzi protozoan, which is an etiological agent of Chagas disease. These vectors have been grouped in complexes and subcomplexes, based mainly on their morphological characteristics and geographical distributions (Schofield and Galvão, 2009).

The Maculata subcomplex is composed of the species Triatoma arthurneivai Lent and Martins 1940, T. maculata Erichson 1848, T. pseudomaculata Corrêa and Espínola 1964, and T. wygodzinskyi Lent 1951. T. maculata and T. pseudomaculata are allopatric, because the former has the following wide geographical distribution: Colombia, Guyana, Aruba, Bonaire, Curação, Suriname, Venezuela, and Brazil (Lent and Wygodzinsky, 1979; Carcavallo et al., 1997), whereas the latter is only found in Brazil, the Brazilian northeast being the probable center of dispersion for this species (Lent and Wygodzinsky, 1979; Freitas et al., 2005). Schofield (1988) proposed that T. maculata was introduced into the Brazilian northeast by passive transportation of the nymphs between the feathers of migratory birds, followed by the speciation of T. pseudomaculata. These species are morphologically very similar, and until 1964 were considered the same species (Corrêa and Espínola, 1964). However, their status as separate species has been confirmed by experimental hybrid crosses (Belisário et al., 2007), and they have been differentiated by cytogenetic analysis (Dos Santos et al., 2007).

T. pseudomaculata is the second most epidemiologically important species in the northeast of Brazil after T. brasiliensis (Carbajal de la Fuente et al., 2009). This species typically exhibits wild and peridomiciliar behavior; however, it can occasionally occur in human habitations (Silveira and Vinhaes, 1998). It is considered endemic to the Caatinga and Cerrado Provinces (Morrone, 2006), but has been reported in the States of Alagoas, Bahia, Ceará, Distrito Federal, Goiás, Maranhão, Minas Gerais, Mato Grosso do Sul, Mato Grosso, Paraíba, Pernambuco, Piauí, Rio Grande do Norte, Sergipe, and Tocantins (Gurgel-Gonçalves et al., 2012). The objective of the present study was to cytogenetically analyze different populations of $T$. pseudomaculata from different Brazilian states, in order to investigate possible intraspecific chromosomal variation between them. 


\section{MATERIAL AND METHODS}

Three adult T. pseudomaculata males from each population (Pernambuco, Ceará, Paraíba, Bahia, Rio Grande do Norte, and Piauí) were analyzed. The insects were donated by "Insetário de Triatominae" of the Biological Sciences Department of the Faculty of Pharmaceutical Sciences, State University of São Paulo, Campus Araraquara, São Paulo, Brazil. Microscope slides with the biological material (seminiferous tubules) were prepared by the crushing technique, and stained with lacto-acetic orcein (De Vaio et al., 1985) with modifications by Alevi et al. (2012) and C-banding (Sumner, 1972). The samples were observed using a Jenaval light microscope (Zeiss) coupled to a digital camera and an AxioVision LE 4.8 image analyzer (Zeiss). The images were magnified by $1000 \mathrm{X}$.

\section{RESULTS}

All of the specimens exhibited the same cytogenetic characteristics, i.e., 22 chromosomes (20 autosomes and $X Y$ ), a chromocenter formed by the $X$ and $Y$ sex chromosomes and one pair of autosomes, and heterochromatin blocks in three or four pairs of autosomes (Figure 1 and Table 1).
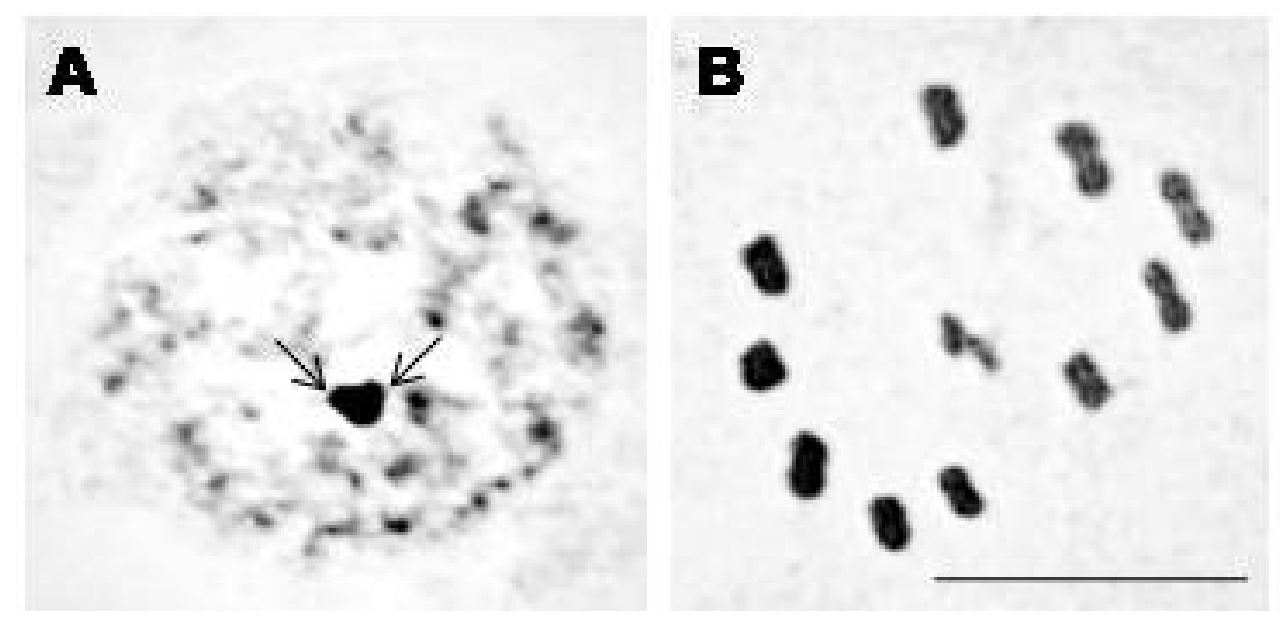

Figure 1. Cytogenetic characteristics of Triatoma pseudomaculata from Paraíba, Brazil. A. Chromocenter formed by $X$ and $Y$ sex chromosomes plus one pair of autosomes (arrows) during initial prophases. B. Karyotype with 22 chromosomes and heterochromatin in three or four autosomes during metaphase I. Bar: $10 \mu \mathrm{m}$.

\begin{tabular}{|c|c|c|c|}
\hline State & Karyotype & Chromocenter & Heterochromatin \\
\hline Pernambuco $^{1}$ & $22(20 A+X Y)$ & $\mathrm{X} Y$, and one pair of autosomes & Some autosomes $+Y$ \\
\hline Ceará ${ }^{1}$ & $22(20 \mathrm{~A}+\mathrm{XY})$ & $\mathrm{X}, \mathrm{Y}$, and one pair of autosomes & Some autosomes $+Y$ \\
\hline Paraíba & $22(20 \mathrm{~A}+\mathrm{XY})$ & $\mathrm{X}, \mathrm{Y}$, and one pair of autosomes & Some autosomes $+Y$ \\
\hline Bahia $^{1}$ & $22(20 A+X Y)$ & $\mathrm{X}, \mathrm{Y}$, and one pair of autosomes & Some autosomes $+Y$ \\
\hline Rio Grande do Norte & $22(20 A+X Y)$ & $\mathrm{X}, \mathrm{Y}$, and one pair of autosomes & Some autosomes $+Y$ \\
\hline Piaui $^{1}$ & $22(20 A+X Y)$ & $\mathrm{X}, \mathrm{Y}$, and one pair of autosomes & Some autosomes $+Y$ \\
\hline
\end{tabular}

Dos Santos et al. (2007). 


\section{DISCUSSION}

The Triatominae subfamily exhibits very little variation in chromosomal number, because all of the species have between 21 and 25 chromosomes (Panzera et al., 1998; Alevi et al., 2013). Variation usually occurs by the fragmentation of the $X$ sexual chromosome, resulting in different mechanisms of sexual determination $\left(X Y, X_{1} X_{2} Y\right.$, or $\left.X_{1} X_{2} X_{3} Y\right)$ (Ueshima, 1966). However, although the number of chromosomes is fairly conserved, triatomines exhibit a large variety of C-banding patterns and interspecific and intraspecific chromosome behaviors during male meiosis (Panzera et al., 1997, 1998, 2004; Alevi et al., 2015b).

Intraspecific chromosome variation in the Triatominae has been analyzed in 10 species (Table 2). Six species exhibit chromosomal variation, which resulted in important publications, as the division of different T. infestans into Andean and non-Andean populations (Panzera et al., 2004), and indicates that cryptic speciation has occurred in T. sordida (Panzera et al., 1997) and Panstrongylus geniculatus (Crossa et al., 2002).

Table 2. Intraspecific variation in triatomine species.

\begin{tabular}{l|l|l}
\hline Species & Intraspecific chromosome variation & Reference \\
\hline R. ecudoriensis & Present & Pita et al. (2013) \\
\hline R. pallescens & Present & Gómez-Palacio et al. (2008) \\
\hline P. geniculatus & Present & Crossa et al. (2002) \\
\hline T. dimidiata & Present & Panzera et al. (2006) \\
\hline T. infestans & Present & Panzera et al. (2004) \\
\hline T. sordida & Present & Panzera et al. (1997) \\
\hline R. neglectus & Absent & Alevi et al. (2015c) \\
\hline P. megistus & Absent & Alevi et al. (2015d) \\
\hline$T$. brasiliensis & Absent & Panzera et al. (2000) \\
\hline$T$. pseudomaculata & Absent & This study \\
\hline
\end{tabular}

Cytogenetic analysis of $T$. pseudomaculata revealed that this species, in addition to the three other species already analyzed, exhibits no intraspecific variation (Table 2). Our results for the States of Pernambuco, Ceará, Bahia, and Piauí were the same as those obtained by Dos Santos et al. (2007). These data confirm that all of the populations analyzed were T. pseudomaculata, and although they may be subject to different selection pressures they have maintained the genetic integrity that characterizes the species.

\section{Conflicts of interest}

The authors declare no conflict of interest.

\section{ACKNOWLEDGMENTS}

Research supported by Fundação de Amparo à Pesquisa do Estado de São Paulo (FAPESP; Process \#2013/19764-0), Fundação de Apoio à Pesquisa e Extensão de São José do Rio Preto (Process \#94/2015) and Conselho Nacional de Desenvolvimento Científico e Tecnológico (CNPq). 


\section{REFERENCES}

Alevi KCC, Mendonça PP, Pereira NP, Rosa JA, et al. (2012). Karyotype of Triatoma melanocephala Neiva and Pinto (1923). Does this species fit in the Brasiliensis subcomplex? Infect. Genet. Evol. 12: 1652-1653.http://dx.doi.org/10.1016/j. meegid.2012.06.011

Alevi KCC, Rosa JA and Azeredo Oliveira MTV (2013). Mini review: karyotypic survey in Triatominae subfamily (Hemiptera, Heteroptera). Entomol. Ornithol. Herpetol. 2: 106. http://dx.doi.org/10.4172/2161-0983.1000106

Alevi KCC, Moreira FFF, Jurberg J and Azeredo-Oliveira MTV (2015a). Description of diploid chromosome set of Triatoma pintodiasi (Hemiptera, Triatominae). Genet. Mol. Res., in press. http://dx.doi.org/10.4238/2015.February.6.14

Alevi KCC, de Oliveira J, Moreira FFF, Jurberg J, et al. (2015b). Chromosomal characteristics and distribution of constitutive heterochromatin in the Matogrossensis and Rubrovaria subcomplexes. Infect. Genet. Evol. 33: 158-162.http://dx.doi. org/10.1016/j.meegid.2015.04.024

Alevi KCC, Rodas LAC, Tartarotti E, Azeredo-Oliveira MTV, et al. (2015c). Entoepidemiology of Chagas disease in the Western region of the State of São Paulo from 2004 to 2008, and cytogenetic analysis in Rhodnius neglectus (Hemiptera, Triatominae). Genet. Mol. Res. 14: 5775-5784.http://dx.doi.org/10.4238/2015.May.29.9

Alevi KCC, Nunes GM, Rosa JA and Azeredo-Oliveira MTV (2015d). Homogeneidade cromossômica em diferentes populações de Panstrongylus megistus do Brasil. Rev. Cienc. Farm. Básica e Aplic. 36: 307-310.

Belisário CJ, D'Ávila Pessoa GC and Diotaiuti L (2007). Biological aspects of crosses between Triatoma maculata (Erichson, 1848) and Triatoma pseudomaculata Corrêa \& Espínola, 1964 (Hemiptera: Reduviidae). Mem. Inst. Oswaldo Cruz 102: 517-521.http://dx.doi.org/10.1590/S0074-02762007005000029

Carbajal de la Fuente AL, Porcasi X, Noireau F, Diotaiuti L, et al. (2009). The association between the geographic distribution of Triatoma pseudomaculata and Triatoma wygodzinskyi (Hemiptera: Reduviidae) with environmental variables recorded by remote sensors. Infect. Genet. Evol. 9: 54-61.http://dx.doi.org/10.1016/j.meegid.2008.09.008

Carcavallo RU, Girón IG, Jurberg J, Galvão C, et al. (1997). Chaves gráficas para as tribos, gêneros e espécies da sub-família Triatominae. In: Atlas of Chagas Disease Vectors in the Americas (Carcavallo RU, ed.). Fiocruz, Rio de Janeiro, 107-244.

Corrêa RR and Spínola HN (1964). Descrição de Triatoma pseudomaculata, nova espécie de triatomíneo de Sobral, Ceará (Hemiptera, Reduviidae). Arq. Hig. Saude Publica 29: 115-127.

Crossa RP, Hernández M, Caraccio MN, Rose V, et al. (2002). Chromosomal evolution trends of the genus Panstrongylus (Hemiptera, Reduviidae), vectors of Chagas disease. Infect. Genet. Evol. 2: 47-56.http://dx.doi.org/10.1016/S15671348(02)00063-1

De Vaio ES, Grucci B, Castagnino AM, Franca ME, et al. (1985). Meiotic differences between three triatomine species (Hemiptera: Reduviidae). Genetica 67: 185-191. http://dx.doi.org/10.1007/BF02424489

Dos Santos SM, Lopes CM, Dujardin JP, Panzera F, et al. (2007). Evolutionary relationships based on genetic and phenetic characters between Triatoma maculata, Triatoma pseudomaculata and morphologically related species (Reduviidae: Triatominae). Infect. Genet. Evol. 7: 469-475.http://dx.doi.org/10.1016/j.meegid.2007.01.008

Freitas SPC, Lorosa ES, Rodrigues DCS, Freitas AL, et al. (2005). [Feeding patterns of Triatoma pseudomaculata in the state of Ceara, Brazil]. Rev. Saude Publica 39: 27-32.http://dx.doi.org/10.1590/S0034-89102005000100004

Gómez-Palacio A, Jaramillo-Ocampo N, Triana-Chávez O, Saldaña A, et al. (2008). Chromosome variability in the Chagas disease vector Rhodnius pallescens (Hemiptera, Reduviidae, Rhodniini). Mem. Inst. Oswaldo Cruz 103: 160-164.http:// dx.doi.org/10.1590/S0074-02762008000200006

Gurgel-Gonçalves R, Galvão C, Costa J and Peterson AT (2012). Geographic distribution of chagas disease vectors in Brazil based on ecological niche modeling. J. Trop. Med. 2012: 705326.http://dx.doi.org/10.1155/2012/705326

Lent $\mathrm{H}$ and Wygodzinsky P (1979). Revision of the Triatominae (Hemiptera: Reduviidae) and their significance as vector of Chagas's disease. Bull. Am. Mus. Nat. Hist. 163: 123-520.

Morrone JJ (2006). Biogeographic areas and transition zones of Latin America and the Caribbean islands based on panbiogeographic and cladistic analyses of the entomofauna. Annu. Rev. Entomol. 51: 467-494.http://dx.doi.org/10.1146/ annurev.ento.50.071803.130447

Panzera F, Hornos S, Pereira J, Cestau R, et al. (1997). Genetic variability and geographic differentiation among three species of Triatomine bugs (Hemiptera-Reduviidae). Am. J. Trop. Med. Hyg. 57: 732-739.

Panzera F, Scvortzoff E, Perez R, Panzera Y, et al. (1998). Cytogenetics of Triatomines. In: Atlas of Chagas Disease Vectors in the Americas (Carcavallo RU, ed.). Fiocruz, Rio de Janeiro, 621-664.

Panzera F, Pérez R, Nicolini P, Hornos S, et al. (2000). Chromosome homogeneity in populations of Triatoma brasiliensis Neiva 1911 (Hemiptera - reduviidae - triatominae). Cad. Saude Publica 16 (Suppl 2): 83-88.http://dx.doi.org/10.1590/ $\underline{\text { S0102-311X2000000800009 }}$

Panzera F, Dujardin JP, Nicolini P, Caraccio MN, et al. (2004). Genomic changes of Chagas disease vector, South America. 
Emerg. Infect. Dis. 10: 438-446.http://dx.doi.org/10.3201/eid1003.020812

Panzera F, Ferrandis I, Ramsey J, Ordòñez R, et al. (2006). Chromosomal variation and genome size support existence of cryptic species of Triatoma dimidiata with different epidemiological importance as Chagas disease vectors. Trop. Med. Int. Health 11: 1092-1103.http://dx.doi.org/10.1111/j.1365-3156.2006.01656.x

Pita S, Panzera F, Ferrandis I, Galvão C, et al. (2013). Chromosomal divergence and evolutionary inferences in Rhodniini based on the chromosomal location of ribosomal genes. Mem. Inst. Oswaldo Cruz 108: 376-382.http://dx.doi.org/10.1590/ S0074-02762013000300017

Schofield CJ (1988). Biosystematics of the Triatominae. In: Biosystematics of haematophagous insects (Service MW, ed.). Clarendon Press, Oxford.

Schofield CJ (1994). Triatominae. Biology and control. Eurocommunica Publications, London.

Schofield CJ and Galvão C (2009). Classification, evolution, and species groups within the Triatominae. Acta Trop. 110: 88100.http://dx.doi.org/10.1016/j.actatropica.2009.01.010

Silveira AC and Vinhaes M (1998). Doença de Chagas: aspectos epidemiológicos e de controle. Rev. Soc. Bras. Med. Trop. 31 (Suppl 2): 15-60.

Sumner AT (1972). A simple technique for demonstrating centromeric heterochromatin. Exp. Cell Res. 75: 304-306.http:// dx.doi.org/10.1016/0014-4827(72)90558-7

Ueshima N (1966). Cytotaxonomy of the triatominae (Reduviidae: Hemiptera). Chromosoma 18: 97-122. http://dx.doi. org/10.1007/BF00326447 